\title{
The Link between Innovation, Market Orientation and Performance; and the Mediating Role of Innovation: A Study of Telecommunication Companies in Ghana
}

\author{
Jennifer Lartey*, Xiangrui Meng, Xiangqian Wang, Gifty Osei-Mireku \\ School of Economics and Management, Anhui University Science and Technology, Huainan, China \\ Email: *je_naad@yahoo.com, xrmeng@aust.edu.cn, xqwaust@163.com, ei.gom@gmail.com, giftymirekuosei.gom@gmail.com
}

How to cite this paper: Lartey, J., Meng, X. R., Wang, X. Q., \& Osei-Mireku, G. (2020). The Link between Innovation, Market Orientation and Performance; and the Mediating Role of Innovation: A Study of Telecommunication Companies in Ghana. Open Journal of Business and Management, 8 , 1704-1733.

https://doi.org/10.4236/ojbm.2020.84108

Received: July 1, 2020

Accepted: July 24, 2020

Published: July 27, 2020

Copyright $\odot 2020$ by author(s) and Scientific Research Publishing Inc. This work is licensed under the Creative Commons Attribution International License (CC BY 4.0).

http://creativecommons.org/licenses/by/4.0/

\begin{abstract}
Telecommunications sector sustainability is hinged on the ability of the company to take the risk of innovation. The primary goal of the study was to investigate the association between innovation and performance. A structured questionnaire is used by the study to extract the data from a population of 300. A structural equation model was adopted to evaluate the relationship between innovation and performance and to use innovation as a mediator to identify the relationship between market orientation, innovation, and efficiency. The findings show that performance is influenced by innovation. Market orientation is strongly and significantly correlated with creativity, which in effect increases firm efficiency. The study impacts existing literature by confirming the connection between innovation and performance using the innovation types. The findings of this paper provide an overview of market orientation and how an organization can take advantage of this behavior to gain competitive advantage from other organizations in the same field. It moreover indicates that managers should pay attention to market orientation to generate new goods, services and ideas, particularly customer orientation. Managers aiming to improve firm efficiency should be sufficiently versatile to experiment with the various forms of creativity. However, innovation is also considered an expensive and dangerous practice; unless the benefits are done properly, the drawbacks outweigh.
\end{abstract}

\section{Keywords}

Innovation, Performance, Market Orientation, Telecommunication, SEM 


\section{Introduction}

Nintendo, a Japanese multinational consumer electronics and video game remained influential in the world of video gaming, reinventing itself through a modern game that powered gamers of all ages and gender. "Pokémon Go" combines augmented reality technology, gamification and scale exchange in a way that has never been achieved with such precision. Every business owner and manager have come to understand that something adequate is needed to succeed in business. Besides key management, communication, preparation, managing and coordinating skills, employers recognize another essential element, creativity.

Innovation is simply an uncommon way of thinking that brings diverse and efficient solutions to modern problems. Long-term economic development can be accomplished by creativity, says the Organization for Economic Co-operation and Development (OECD, 2010). Innovation: a strategic economic growth tool has offered most companies a competitive edge at both national and corporate level (Cefis \& Marsili, 2005; Tellis, Prabhu, \& Chandy, 2009; De Silva, Howells, \& Meye, 2018).

The term innovation did not just evolve; it has been in existence for some time now. Majority of management theories arrive at one conclusion; innovation is the key that opens the door to success for most organizations (Baker \& Sinkula, 1999; Balkin et al., 2000; Darroch \& McNaugton, 2002; Lyon \& Ferrier, 2002; Utterback, 1994; Vrakking, 1990; Wolfe, 1994). The interest in innovation has led to several studies aimed at identifying factors that promote innovation (Koc \& Ceylan, 2007). Some research explored a wide variety of innovation determinants from firm-specific characteristics (Tidd et al., 2001) to external environment impact (Damanpour, 1991).

The past decade has been marked by an increasingly wider interest in market orientation (Narver \& Slater, 1990; Ruekert, 1992; Jaworski \& Kohli, 1993; Lambin, 1996; Deng \& Dart 1994), as well as in the useful way of enhancing economic performance. It is still not well understood, however, why such an effect exists, and especially how it operates. Terms such as market-oriented, market-driven, and customer-focused in companies around the world have become synonymous with constructive business strategy. The notion that the customer must be at the origin of business planning processes appears to be very contemporary, as does the idea of organizing the company's activities around a thorough understanding of customer needs and demands (Desphandé \& Farley, 1999).

Innovation, market orientation and performance relate and intertwine in a positively. However previously studies hardly incorporate market orientation when analyzing the innovation and performance link. Previous studies explore the relationship innovation has with factors such as organizational culture (Keskin, 2006; Lee \& Tsai, 2005). Other studies also analyze the innovativeness of the organization using only product innovation (Salavou \& Lioukas, 2003). Hence research studies innovativeness from just a particular point leading to a 
limited idea of innovation.

To add to it, there have been some inconsistencies in the results between innovation and performance. This gives the impression that more research needs to be conducted in the area with different constructs associated with innovation.

The telecommunications industry, or telecom industry, consists of companies providing data transmission and communications infrastructure. It includes, among others, cable and cellular service providers, several types of Internet service providers and fiber optic networks. In the last quarter of the twentieth century, telecommunications became the economy's central nervous system. Just as railways once fostered economic growth and development, telecommunications are now globalizing economies, rising transaction costs, growing efficiency, and directly increasing economic well-being (Haring, 2002).

The survival of telecommunications is undeniably important to any country's development. This has led some scholars to study competition among key industries (Brennan et al., 2015; Bagheri \& Di Minin 2015; Breitschwerdt et al., 2016), in the economy which includes telecommunication (Yaseen et al., 2016) as well.

This study attempts to address the flaws of related existing literature using the telecommunications industry as its study focus. The study analyzes the association between innovation, market orientation and performance using a single model. The study also integrates the other category of innovation in its measurements. In addition the paper will also address the inconsistency in the result of innovation and performance link using a different geographical context from other papers.

\section{Literature Review and Hypothesis Development}

\subsection{Innovation}

Past and recent innovation studies have led to the idea that innovation can be both a process and an outcome (Damanpour \& Gopalakrishnan, 1998; Damanpour et al., 1989; Knight, 1967; Nord \& Tucker, 2001; Rogers, 1995; Thompson, 1965; Wolfe, 1994). The process and/or outcome of the dispute does not change the definition of innovation, and therefore the phrase that runs through most of the definitions of innovation is "the adoption of new ideas and behaviors." The term innovation has been in existence since the early centuries and has gradually become increasingly popular and widely researched in recent years. For example, Hurley and Hult (1998) saw innovation as an aspect of the company's culture and openness to new ideas. This explanation has been extended to provide a more in-depth understanding. Crossan and Apaydin (2010), define innovation as 'the production or adoption, assimilation and exploitation of value added novelty in the economic social sphere; the renewal and expansion of products, services and markets; the development of new production methods and the establishment of new management systems". 
In a more simplified form, innovation can be defined as an in-depth process aimed at transforming existing products or services, production/distribution as well as social services. Organizations engage in innovative activities in areas such as product, process and marketing methods, internal application organizational methods, work-place organization or external relations (Tirupati, 2008: p. 105). Various categories of innovations vary from literature to literature. Innovation can be said to be either radical or incremental (e.g. Subramaniam \& Youndt, 2005), technical or ad related. The most widely accepted and widely used is the one proposed by Damanpour (1991). It goes beyond the general categories; product and process; and distinguishes between technical and administrative innovations. Technical innovations involve new products or services and processes, while administrative innovations consist of new procedures, policies and organizational forms (Dewar \& Dutton, 1986; Evan, 1966; Hage, 1980; Normann, 1971; Tushman \& Nadler, 1986; Utterback \& Abernathy, 1975). Product, process, marketing, strategic, behavioral innovations are the main source of competitive advantage and the combination of new resources and information develops the competitiveness of enterprises (Wang \& Ahmed, 2004). Organizational innovations deal with drawing and mapping out new strategies and business procedures or plans, in the workplace or in the external relations of the firm. Organizational innovation encompasses processes that generate new manufacturing and management templates that can be applied to both tangible and intangible resources. Marketing innovations describe the application of novel marketing ideas and methods, which may include modification to existing product design and its packaging, product promotion and placement, and pricing methods for goods and services.

Innovation is a managerial and organizational commitment that suggests new ways to promote corporate responsibility by rebuilding the relationship between the organizations and the customers it serves (Lenssen, Tyson, Pickard, Bevan, \& Bartlett, 2009). Firms tend to innovate due to external pressures that may take the form of competition, industrial deregulation, scarcity of limited resources, and higher customer demands. It could also be the result of internal organizational alternatives, which could include gaining unique skills, achieving a higher level of ambition, and improving the scope of quality service delivery (Damanpour et al., 2009).

Innovation is made up of some technical knowledge of how strategies that are currently being implemented can be improved (Tyler, 2001). The processes that businesses need to pursue or achieve innovative success include the acquisition of knowledge, the dissemination of knowledge and the use of knowledge through creative implementation (Amabile, Conti, Coon, Lazenby, \& Herron, 1996; Calantone et al., 2002). There is broad consensus on and linkages between corporate entrepreneurship, learning climate and innovation (Liu, 2009). Corporate entrepreneurship is critical when it comes to innovation, as it focuses on risk-taking, experimentation, proactive change, and innovative engagement 
(Baker \& Sinkula, 1999).

While organizational innovation is a precondition for the effective use of innovative tools and emerging technologies, the carrying out of advanced technology also poses complicated chances and difficulties which eventually leads to different management processes and new organizational types (Lam, 2004). New innovations make implementing new management types feasible. The incorporation of emerging technology and the connection to improvements in the workforce has contributed to "skill-based technological change", i.e. the adoption of new technologies, creating a bias against more skilled employees to ensure that such new technologies are used correctly (Xue et al., 2008).

Innovation is a controversial subject, full of mixed opinions and mixed conclusions. For instance, a study conducted by Wright et al. (2005) found that product innovation causes no significant changes in performance in favourable environments, but this may change in unfriendly and unreceptive has an environment.

Earlier studies have shown similar results to those of Wright. Birley and Westhead (1990); Heunks (1998), unveiled that innovation does not influence business performance. Other studies such as Caves and Ghemwat, 1992 (e.g. Damanpour, 1991; i.e. Damanpour \& Evan, 1984; Damanpour et al., 1989; Hansen et al., 1999; Roberts, 1999; Schulz \& Jobe, 2001; Thornhill, 2006; Weerawardena et al., 2006; Wheelwright \& Clark, 1992) announce the same thing.

On the other hand, several distinct studies refer to a definite correlation with relationship innovation has with firm success (e.g. Johne \& Davies, 2000; Marques et al., 2011; Hatzikian, 2013; Hashi \& Stojčić, 2013), suggesting that the most creative companies concentrate more on management techniques. This helps them to achieve higher success levels (e.g. Guan \& Ma, 2003). Several literatures calls for research that help quantify the effect of innovation on firm results (e.g., Rosenbusch et al., 2011; Santos et al., 2014).

Much more recent literature (Simpson et al., 2006) points out that innovation is quite complex and therefore expensive and risky. Innovation not only produces outstanding and peculiar results on firm performance, but also has a tendency to negatively affect the organization, such as increased exposure to market risk, increased costs, and dissatisfaction with employees or unjustified changes.

Most of the broad empirical studies on the relationship between innovation and performance show that this relationship is positive (Li \& Atuahene-Gima, 2001; Guo et al., 2005; Leal-Rodríguez et al., 2015).

Other studies also show a significant positive relationship between innovation and firm performance (Rosenbusch et al., 2011; Koellinger, 2008; Vincent et al., 2004; Omri, 2015; Calantone et al., 2002; Lado \& Maydeu-Olivares, 2001).

This paper takes and joins those with the notion that innovation has a positive effect on performance therefore the aim of this paper is to analyze the impact of innovation on performance, thus looking at innovation in the broad concept of 
the adoption of new processes, products, innovation of the Organization.

\subsection{Market Orientation}

Growing interest in innovation has also given rise to an interest in market orientation. Various definitions and explanations for the concept of market orientation have been provided. Empirical studies underscore the notion that firms with a higher market orientation achieve high economic and commercial results. Market orientation, when is viewed critical by an organization, causes change as well as new avenues for the firm and, most importantly, gives the organization a higher hand when it comes to competition (Narver \& Slater, 1990; Kohli et al., 1993). The works of Kohli and Jaworski (1990), Narver and Slater (1990) and Deshpandé et al. (1993) formalised the term market orientation and divided it into culture and behavior. Market orientation as a culture is seen as a lifestyle of an organization committed to its customers as a value. With this view in mind, Narver and Slater (1990) defined market orientation as a business culture that affects the creation of superior customer value through three components, such as customer orientation, competitor orientation and inter-functional orientation. In contrast, market orientation as behavior is seen as an act that is specifically geared to the market information process (Hult et al., 2005) and aimed at collecting such information and carefully dispersing relevant information about customers and competitors across the responsive organization (Kohli \& Jaworski, 1990). According to Slater and Naver, the market orientation can be seen as an innovative behavior because it involves a constant change in response to market demand. There is one major and interesting dispute over market orientation and innovation, namely that the latter influences the other, or rather causes a gradual change in products due to market orientation and innovation.

The template is used to format your paper and style the text. All margins, column widths, line spaces, and text fonts are prescribed; please do not alter them. You may note peculiarities. For example, the head margin in this template measures proportionately more than is customary. This measurement and others are deliberate, using specifications that anticipate your paper as one part of the entire journals, and not as an independent document. Please do not revise any of the current designations.

\subsection{Performance}

Most organizations validate their performance based on how best they were able to achieve their set goals and objectives. They compare how much they have improved from one stage to the other during the past years.

Akande (2011) sees performance as the will to assess if a company has achieved success, and this can take place in either small scale or large companies. The scale, number of workers, working capital and productivity may be used for evaluating companies.

A firm's performance is seen as the ability to run the organization well and the 
interest and efforts it has to please its stakeholders (Moullin, 2003). Business performance on whole can be seen from two different angles that is from a judgmental point and an objective point (Agarwal et al., 2003; Guo, 2002). What makes judgement measure different from objective measure in a couple of service-related businesses is that judgmental performance measures are of significance to profitability, whereas objective performance measures make more profitability clearer (Agarwal et al., 2003). Some objective measures include Return on Equity (ROE), sales growth and Return on Asset (Shariff, Peou, \& Ali, 2010). Subjective measures include employee engagement and satisfaction, consumer happiness and loyalty and low customer dissatisfaction which also help to build a sustainable shareholder value (Cumby \& Conrod, 2001).

Hamon (2003) defined Organizational Performance (OP) as a variable that is used to determine OP's level to achieve the goals, the efficiency as well as the effectiveness of the organizations to attain its desired (Robbins \& Coulter, 2002). The efficiency is essentially calculated by market productivity according to Heskett and Schlesinger (1994).

The organization's Customer Relationship Management (CRM) procedures, retention of customers, loyalty, customer satisfaction and lifetime value (LTV) can be measured using a judgmental and analytical procedure for a service organization

Existing studies appreciate the holistic measure of performance. Financial measures or using a single measure does not really reflect the performance level of the organization (Quinn \& Rohrbaugh, 1983; Venkatraman \& Ramanujam, 1986).

\subsection{Innovation and Performance}

Companies need to build specific and useful capabilities for customers to achieve competitive advantage. Competition (Walker, 2009: p. 50) is needed to maintain generated competitive advantage preventing emulation and replacement of these capabilities (Barney, 1991). An innovative approach enables firms to cope better with extremely complex, unpredictable, and highly uncertain environments, allowing firms to pursue new oppositions.

During this era of sophisticated computers, managers want flexibility and the freedom to be innovative and discover new methods of solving problems (Gómez, Salazar, \& Vargas, 2017). The potential of creative companies to be more versatile and open to change; gives them the distinctive characteristic of generating new opportunities and exploiting existing ones (Drucker, 1985).

Past research and literature have shown that innovation is a key driver of the long-term success of any organization, particularly in a dynamic market (Damanpour \& Gopalakrishan, 2001). The idea surrounding this notion is that innovation often helps to deal with a harsh external environment, and that, in order for an organization to survive in a Schumpeterian, it has to cope with complexity and high-speed change. The extent to which an organization is able to innovate will determine the rate at which it responds to challenges, the manu- 
facturing of newly improved products, and how it exploits market opportunities in comparison with non-innovative companies (Jiménez-Jiménez, Sanz-Valle, \& Rodriguez-Espallardo, 2008).

Some studies also posit that the extent to which innovation can actually have an impact on performance depends on the type of innovation (Gunday et al., 2011) that is product, process, organizational/marketing innovation and type of industry.

The ever-increasing interest in innovation in organizations suggests support in previous literature which suggests a positive link between innovation and a range of desired performance outcomes (e.g. García-Morales, Jiménez-Barrionuevo, \& Gutierrez, 2011; Han, Kim, \& Srivastava, 1998).

Past researchers have employed multiple in-house variables such as new product success, financial performance, non-financial performance to assess the effect of any new organizational transition whether technical, political, and social, etc. In a Vietnam Developing Economy report, Tuan et al. (2016) found support for product innovation. In an automotive analysis, Zaefarian et al. (2017) found that effective product innovation has a positive correlation with firm efficiency. To examine the effect of product innovation on company results, Jajja et al. (2017) analyzed 296 Indian and Pakistani companies. They find that product innovation not only affects the company, but also inculcates supplier-centered innovation and further strengthens buyer-supplier relationship. Haleem et al. (2018) suggested that product innovation management would draw new consumers, and hence the competitive advantage for firms.

A recent study found that process improvement had a positive and significant effect on new product performance in the Iranian manufacturing industries (Najafi-Tavani et al., 2018). Piening and Salge (2015) established that process innovation has a positive association with firm performance. They also found that both technical instability and market volatility positively influence the relationship between a company's process innovation and its financial performance. Similarly, for this relationship in Vietnam, Tuan et al. (2016) argued similar course. Baer and Frese (2003) concluded that success in organizations with process innovation depends on the correct environment for implementing these innovations. They said managers taking this initiative need psychological protection to push such transition. Process innovation is also considered, and found important, as a moderating variable for establishing a relationship between business systems and operational efficiency (Chang et al., 2019).

Using a selected business service firm in the USA, Mansury and Love (2008) unveiled that incorporating service innovation enhances the growth process of a company but does not alter productivity. Another study piloted in the United Kingdom by the public service (Damanpour et al., 2009) found that it is acceptable to be flexible in adopting innovation-based strategies on a yearly basis. The study explained that consistency in the applying the same design of innovation types (service, technological, and administrative) periodically, has no effect. A firm that is quick to explore other types of innovation is boosting its perfor- 
mance. Various explanations and findings only confirm the belief that the connection between innovation and performance is knotty and needs more research. This paper seeks to further explore the positive link between innovation types and performance.

\subsection{Market Orientation and Performance}

Whatever motivates companies to innovate, the aim is to facilitate adaptive behavior and to improve and improve the performance of changing trends in the firm (Agarwal et al., 2003; Calantone et al., 2002; Lee \& Tsai, 2005). It is worth supporting the view that market orientation and business innovation should have the capacity to complement each other and that whether market orientation is proactive or responsive should serve as a strong foundation for the company's innovative efforts (Han, Kim, \& Srivastava, 1998; Hurley \& Hult, 1998; Narver, Slater, \& MacLachlan, 2004).

Some studies have agreed to the idea of positive association in relation to market orientation and business performance as it relates to a wide range of businesses (Campo et al., 2014; Lee et al., 2015; Peña et al., 2012; Wang et al., 2012), while others have found no affirmation that Market Orientation is directly connected to firm performance (Au \& Tse, 1995; Sargeant \& Mohamad, 1999). It has been discovered that the association between $\mathrm{MO}$ and performance can be mediated by variables such as innovation (Agarwal et al., 2003; Sandvik \& Sandvik, 2003). In addition, according to an analysis review by Kirca et al. (2005), the direction of the relationship between MO and performance ranges widely from an elevated ratio of $\mathrm{r} 1 / 40.37$ in manufacturing firms to a low of $\mathrm{r}$ $1 / 40.26$ in service firms.

Existing studies such as Augusto and Coelho, 2009; Christensen and Bower, 1996; Dibrell et al., 2011; Gotteland and Boule, 2006; Hult and Ketchen, 2001; Hult et al., 2005; Kumar et al., 2011; Olavarrieta and Friedmann, 2008; Slater and Narver, 1998; Srivastava et al., 2001 looked at the relationship between market orientation and performance.

Sandvik and Sandvik (2003) explored the impact of innovation on firm performance and found that innovation, which focuses on new market products, promotes sales growth (Cronin \& Page, 1988), attracts price increases (Covin et al., 1999) and helps organisations to operate at maximum capacity (Lee \& $\mathrm{Ng}$, 2001). Studies further revealed that the direct consequence was a strong positive impact on firm profitability. After a study, using dozens of countries, Deshpandé and Farley (2004) concluded that the type of industry does not alter the positive relationship between market orientation and innovation Even though most management books and articles explicitly set the market orientation function as an improvement.

The debate or dispute about market orientation does not change the outcome of the research that validates the positive relationship between market orienta- 
tion and innovation (Baker \& Sinkula, 1999; Greenley, 1995; Lewrick, 2009; Zhou et al., 2005).

Lado and Maydeu-Olivares (2001) also argue that the adoption of market orientation principles has a positive impact on innovation activities, their scale, and their effectiveness.

$\mathrm{H} 2$ : Innovation has a mediating role between market orientation and performance.

\section{Methodology}

\subsection{Data Collection and Sample}

Empirical study was carried out in the three major telecommunication mobile network providers companies in Ghana. The population comprised of managers and employees (more than 300 employees) from the main branches and sub-branches of these telecommunications companies in the capital city of Accra.

\subsection{Research Design}

This study is a quantitative research and this study demanded the use of SEM. This is because structural equation model (SEM) is a multivariate statistical framework that is used to model complex relationships between directly and indirectly observed (latent) variables. The study will test both a direct and an indirect relationship. This study developed an SEM path model to test the hypothesis and run a multivariate regression with two independents variable (innovation and market orientation) and one independent variable (performance).

\subsection{Measurement Instrument.}

Information was collected using a previously tested questionnaire (Jiménez-Jiménez \& Sanz-Valle, 2011). The questionnaire was handed out personally to both managers and employees. A total of 300 questionnaires were obtained from the 350 questionnaires distributed. This equals a response of $86 \%$. The first part of the questionnaires was made up of demographic characteristics such as age, gender, level of education, department he or she belongs to. The variables under study and the scales used are presented below.

\subsubsection{Innovation Scale}

Respondents were to measure innovation in your organization within the past three years while comparing the organization to other organizations in the same sector. This part was divided into three parts based on the types of innovation: process, product, and administrative. Using a five Likert scale respondents were to carefully select from well below to well above for each of the 9 items under innovation. Some items in this section include a number of products/services introduced, pioneer disposition to introduce new products/services. 


\subsubsection{Performance Scale}

A range of performance measure was used without including financial measures. The respondents were asked about the evolution of the organizational performance during the previous three years using items proposed by Quinn and Rohrbaugh (1983). Respondents were also asked to carefully select from a 5 Likert scale of increase to decrease $(5=$ increase $1=$ decrease) for the 12 individual items under four dimensions. Examples of items include timeliness, efficiency, and quality product.

\subsubsection{Market Orientation}

This study is a quantitative research and this study demanded the use of SEM. This is because structural equation model (SEM) is a multivariate statistical framework that is used to model complex relationships between directly and indirectly observed (latent) variables. The study will test both a direct and an indirect relationship. This study developed an SEM path model to test the hypothesis and run a multivariate regression with two independents variable (innovation and market orientation) and one independent variable (performance).

\subsection{Measures}

\subsubsection{Innovation}

This study utilizes six items for each form of innovation-product, process and administrative-in accordance with Manu (1992), in line with the number of innovations, the constructive or reactive nature of such innovations, and the capital that the firm invests in innovation. The confirmatory factor analysis (Table 2) proposes the items for each type of innovation; three items to measure product innovation ( $\rho \mathrm{SCR}=0.78, \rho \mathrm{AVE}=0.54$ ), two items for process innovation ( $\rho c \mathrm{SCR}=0.77, \rho c \mathrm{AVE}=0.61)$ and lastly three for administrative innovation ( $\rho \mathrm{SCR}=0.86, \rho c \mathrm{AVE}=0.68$ ). A second-order factor analysis demonstrates that a higher-order construct can model those three dimensions (Table 4). The outcome proposes a practicable fit of second-order specification for this measure of innovation $\left(\chi^{2}=43.6, \mathrm{df}=17\right.$; GFI $=0.96$; RMSEA $=0.072$; CFI $=$ 0.97; TLI $=0.95)$. GFI, CFI, and TLI are all above the required 0.90 threshold (Hoyle \& Panter, 1995). The RMSEA is about 0.050, within reasonable range. All factor loadings for each construct with respect to its constructs were statistically significant and were 0.5 and above as suggested by Hair et al. (2010). The fit indices from the CFA of all constructs meet the acceptance level, thus confirming the convergent validity and unidimensionality.

\subsubsection{Market Orientation}

The study employed a rotational component matrix approach to select 3 out of the initial 5 indicators of market orientation (MO1, MO4, and MO5) with factors loadings of $0.385,0.957$ and 0.867 respectively. Since there was no second order construct of factors for market orientation, there was no need for any exploratory factor analysis for the three selected indicators. 


\subsubsection{Equations}

In harmony with literature, the questionnaire employed in this research, using items suggested by Quinn and Rohrbaugh (1983), questioned the firms about the metamorphosis of their results over the previous three years. They propose that the idea of organizational success requires different measurements, which corresponds to four basic models of organizational effectiveness: the model of human interactions, the model of internal processes, the model of the open structure and the model of moral goals. Exploratory analysis and confirmatory factor analysis (Table 2) identify only three models: the open/internal system ( $\rho$ S SCR $=0.80, \rho c \mathrm{AVE}=0.57)$, the rational goal model $(\rho \mathrm{CCR}=0.85, \rho \mathrm{AVE}=0.66)$ and internal process model ( $\rho \mathrm{SCR}=0.79, \rho c \mathrm{AVE}=0.56$ ). Additional analysis shows that the second-order construct can model the three performance dimensions (see Table 3 ). The results suggest a good fit of the second-order specification $\left(\chi^{2}=52.86, \mathrm{df}=24\right.$; GFI $=0.965$; $\mathrm{RMSEA}=0.063$; CFI $=0.97$; $\left.\mathrm{TLI}=0.96\right)$. GFI, CFI, and TLI all exceed the recommended threshold level of 0.90 (Hoyle \& Panter, 1995). The RMSEA is close to the acceptable level of 0.050. All the factor loadings for each item were 0.70 and above. The CFA shows that each of the individual items loads significantly to its intended factor, indicating convergent validity among the items for each scale. All factor loadings are highly significant $p<0.001$ indicating the unidimensionality of the measure.

\section{Results and Analysis}

\subsection{Demographics}

Of the 300 questionnaires that were returned, $44 \%$ were found to be female, while $56 \%$ were male. All participants (100 per cent) had a university level of education. In terms of service duration, 19 percent were $1-3$ years in the business, 42 percent were $4-7$ years and 8 years and above 39 percent. Through this study it can be concluded that most respondents are fairly familiar with the organizations. Managers make up 33 per cent, and officers make up 67 per cent of the successful study. A combination of managers "and officers" responses eliminate the biasedness of the responses (Table 1).

\subsection{Correlations, Means and Standard Deviation}

The constructs used in this study are Market Orientation, innovation, and performance. Table 2 outlines the means and standard deviations of the constructs, and the correlations between the variables.

The mean and correlation analyses were computed to assess the significance of the variables to innovation and performance and also to analyze the association between the constructs.

It can be deduced from Table 1 the mean values obtained from the variables reflect that the respondents' opinions about these variables are strongly needed and important for the organization innovation performance. It can also be observed that the OSM and Market Orientation have the highest score that is 4.13 
Table 1. Demographic statistics.

\begin{tabular}{ccccc}
\hline & Frequency & Percent & Valid percent & Cumulative percent \\
\hline Gender & & & & \\
Valid Male & 168 & 44.0 & 44.0 & 44.0 \\
Female & 132 & 56.0 & 56.0 & 44.0 \\
Total & 300 & 100.0 & 100.0 & 100.0 \\
Level of education & & & & \\
Valid University & 300 & 100.0 & 100.0 & 100.0 \\
Length of service & & & & \\
Valid $\quad$ - - years & 58 & 19.3 & 19.3 & 19.3 \\
$4-7$ years & 126 & 42.0 & 42.0 & \\
$8-$ above years & 116 & 38.7 & 38.7 & \\
Total & 300 & 100.0 & 100.0 & \\
Position & & & & 32.7 \\
Valid Manager & 98 & 32.7 & 32.7 & 100.0 \\
Officer & 202 & 67.3 & 67.3 & \\
Total & 300 & 100.0 & 100.0 & \\
\hline
\end{tabular}

Table 2. Correlations, means and standard deviation.

\begin{tabular}{|c|c|c|c|c|c|c|c|c|c|}
\hline \multirow{3}{*}{$\begin{array}{c}\text { Construct } \\
\mathrm{RM}\end{array}$} & \multirow{2}{*}{\multicolumn{2}{|c|}{ Mean St. Dev. }} & \multicolumn{7}{|c|}{ Correlation Matrix } \\
\hline & & & \multirow{2}{*}{$\begin{array}{l}1 \\
1\end{array}$} & \multirow[t]{2}{*}{2} & \multirow[t]{2}{*}{3} & \multirow[t]{2}{*}{4} & \multirow[t]{2}{*}{5} & \multirow[t]{2}{*}{6} & \multirow[t]{2}{*}{7} \\
\hline & 4.02 & 0.69 & & & & & & & \\
\hline OSM & 4.13 & 0.56 & $0.429^{* *}$ & 1 & & & & & \\
\hline IPM & 3.94 & 0.62 & $0.496^{\star *}$ & $0.438^{\star *}$ & 1 & & & & \\
\hline Product & 3.98 & 0.61 & $0.438^{\star *}$ & $0.423^{\star *}$ & $0.484^{\star *}$ & 1 & & & \\
\hline Process & 3.92 & 0.59 & $0.330^{* *}$ & $0.381^{\star *}$ & $0.346^{\star *}$ & $0.508^{* *}$ & 1 & & \\
\hline Administration & 3.83 & 0.57 & $0.298^{\star *}$ & $0.294^{\star *}$ & $0.420^{\star *}$ & $0.361^{\star *}$ & $0.303^{\star *}$ & 1 & \\
\hline Mkt-Orientation & 4.14 & 0.59 & $0.239^{* *}$ & $0.327^{* *}$ & $0.401^{\star *}$ & $0.427^{* *}$ & $0.385^{\star *}$ & $0.411^{\star *}$ & 1 \\
\hline
\end{tabular}

**. Correlation is significant at the 0.01 level (2-tailed).

and 4.14 respectively. This highest scores vividly and openly posits that the Open System Model and market orientation play a major role in the innovation performance in the telecommunication industry in Ghana. In terms of correlation, the correlation matrix table (Table 2 ) show that the constructs are significantly positively related. The correlation analyses are between the constructs of performance (rational model, open system model, internal process model), innovation (process, product and administrative) and market orientation. The most significant relationships are between market orientation and product innovation (0.427), product innovation and rational model (0.438), product innovation and internal process model (0.484) and market orientation and administrative innovation (0.411).

\subsection{Confirmatory Factor Analysis}

This research performs a confirmatory factor analysis of the seven (7) constructs, using 22 objects, to determine the unidimensional of each new construct 
(Anderson \& Gerbing, 1988). The measurement model shown in Table 3, provides a reasonable fit to the data $\left(\chi^{2}=24.91, \mathrm{df}=12\right.$; GFI $=0.98$; RMSEA $=$ 0.060 ; $\mathrm{CFI}=0.98$; $\mathrm{TLI}=0.96$ ). The traditionally reported fit indexes are within the acceptable range.

\section{Reliability and Validity Analysis}

This research measures the reliability of the measurements using the composite reliability index of Bagozzi and Yi (1998), and the average variance derived index of Fornell and Larcker (1981). Both indices are higher for all the variables than the assessment parameters, namely 0.6 for the composite reliability index and 0.5 for the derived average variance index (Bagozzi \& Yi, 1998). All items load onto their expected factors (see Table 2) and the results are positive and significant (the lowest $\mathrm{t}$-value is 20.01), which indicates convergent validity (Bagozzi \& Yi, 1998) (Tables 3-6).

Table 3. Confirmatory factor analysis.

\begin{tabular}{|c|c|c|c|}
\hline Item description & Standardized Loading & T-Value & Reliability $\left(\mathrm{SCR}^{\mathrm{a}}, \mathrm{AVE}^{\mathrm{b}}\right)$ \\
\hline \multicolumn{4}{|l|}{ Administration } \\
\hline $\mathrm{AD} 1$ & 0.806 & 20.20 & $\mathrm{SCR}=0.86$ \\
\hline $\mathrm{AD} 2$ & 0.837 & 23.54 & $\mathrm{AVE}=0.68$ \\
\hline $\mathrm{AD} 3$ & 0.833 & 20.01 & \\
\hline \multicolumn{4}{|l|}{ Production } \\
\hline PROD1 & 0.636 & 27.73 & $\mathrm{SCR}=0.78$ \\
\hline PROD2 & 0.846 & 22.58 & $\mathrm{AVE}=0.54$ \\
\hline PROD3 & 0.706 & 20.60 & \\
\hline \multicolumn{4}{|l|}{ Process } \\
\hline PROC1 & 0.782 & 26.52 & $\mathrm{SCR}=0.77$ \\
\hline PROC3 & 0.775 & 20.86 & $\mathrm{AVE}=0.61$ \\
\hline \multicolumn{4}{|l|}{ Market Orientation } \\
\hline MO1 & 0.440 & 30.38 & $\mathrm{SCR}=0.79$ \\
\hline MO4 & 0.877 & 27.34 & $\mathrm{AVE}=0.58$ \\
\hline MO5 & 0.879 & 28.58 & \\
\hline \multicolumn{4}{|l|}{ IPM } \\
\hline IPM1 & 0.633 & 23.26 & $\mathrm{SCR}=0.79$ \\
\hline IPM2 & 0.810 & 22.49 & $\mathrm{AVE}=0.56$ \\
\hline IPM3 & 0.797 & 22.21 & \\
\hline \multicolumn{4}{|l|}{ RM } \\
\hline RM1 & 0.758 & 25.193 & $\mathrm{SCR}=0.85$ \\
\hline RM2 & 0.871 & 21.520 & $\mathrm{AVE}=0.65$ \\
\hline RM3 & 0.791 & 21.143 & \\
\hline \multicolumn{4}{|l|}{ OsM } \\
\hline OSM1 & 0.705 & 30.38 & $\mathrm{SCR}=0.80$ \\
\hline OSM2 & 0.776 & 27.34 & $\mathrm{AVE}=0.57$ \\
\hline OSM3 & 0.773 & 28.58 & \\
\hline
\end{tabular}

Fit statistics for measurement model of 22 indicators for 7 constructs: $\chi^{2}(12)=24.91$; GFI $=0.98$; RMSEA = 0.060 ; CFI $=0.98$; TLI $(\mathrm{NNFI})=0.96$. a Scale composite reliability $(\rho c=(\Sigma \lambda \mathrm{i}) 2 \operatorname{var}(\xi) /[(\Sigma \lambda \mathrm{i}) 2 \operatorname{var}(\xi)+\Sigma \theta \mathrm{ii}]$; (Bagozzi \& Yi, 1998)). ${ }^{\mathrm{b} A v e r a g e ~ v a r i a n c e ~ e x t r a c t e d ~}\left(\rho \mathrm{c}=\left(\Sigma \lambda_{\mathrm{i}} 2 \operatorname{var}(\xi)\right) /\left[\Sigma \lambda_{\mathrm{i}} 2 \operatorname{var}(\xi)+\Sigma \theta \mathrm{ii}\right](\right.$ Fornell \& Larcker, 1981)). 
Table 4. Second-order confirmatory factor analysis for performance.

\begin{tabular}{cccccc}
\hline \multirow{2}{*}{ First-Order Construct } & \multicolumn{3}{c}{ First-Order } & \multicolumn{2}{c}{ Second-order } \\
\cline { 2 - 6 } & Indicator & Loading & t-value & Loading & t-value \\
\hline \multirow{2}{*}{ RM } & RM1 & 0.72 & 12.56 & 0.76 & 6.4 \\
& RM2 & 0.84 & 15.1 & & \\
& RM3 & 0.84 & a & & \\
OSM & OSM1 & 0.63 & 9.0 & 0.69 & 6.4 \\
& OSM2 & 0.75 & 10.3 & & \\
& OSM3 & 0.75 & a & & \\
& IPM1 & 0.72 & 11.1 & 0.76 & a \\
IPM & IPM2 & 0.87 & 13.3 & & \\
& IPM3 & 0.87 & a & & \\
\hline
\end{tabular}

Fit statistics for measurement model of 9 indicators for 3 constructs: $\chi^{2}(24)=52.86$; GFI $=0.965$; RMSEA = 0.063 ; CFI $=0.973$; TLI $(\mathrm{NNFI})=0.96 . P$-Value $=0.001$. a: Fixed parameter.

Table 5. Second-order confirmatory factor analysis for innovation.

\begin{tabular}{cccccc}
\hline \multirow{2}{*}{ First-Order Construct } & \multicolumn{3}{c}{ First-Order } & & \multicolumn{2}{c}{ Second-order } \\
\cline { 2 - 5 } & Indicator & Loading & t-value & Loading & t-value \\
\hline \multirow{2}{*}{ Production } & Prod1 & 0.63 & 10.1 & 0.87 & 0.50 .4 \\
& Prod2 & 0.77 & 12.7 & 0.77 & $\mathrm{a}$ \\
Processing & Prod3 & 0.85 & $\mathrm{a}$ & & \\
& Proc1 & 0.67 & 7.8 & & 5.52 \\
Administration & Proc3 & 0.80 & & & \\
& Admin1 & 0.75 & 13.4 & & \\
\hline
\end{tabular}

Fit statistics for measurement model of 8 indicators for 3 constructs: $\chi^{2}(17)=43.6$; GFI $=0.964$; RMSEA = 0.072 ; CFI $=0.972$; TLI $(\mathrm{NNFI})=0.953$. $P$-Value $=0.000$. a: Fixed parameter.

Table 6. Market orientation indicators construct.

\begin{tabular}{cccc}
\hline \multirow{2}{*}{ First-Order Construct } & \multicolumn{3}{c}{ First-Order } \\
\cline { 2 - 4 } & Indicator & Loading & t-value \\
Market Orientation & MO1 & 0.385 & 6.2 \\
& MO4 & 0.957 & 6.7 \\
\hline
\end{tabular}

\subsection{Hypothesis Analysis}

The study uses structural equation modeling (SEM) to test the hypotheses. Figure 1 demonstrates the proposed structural model. 


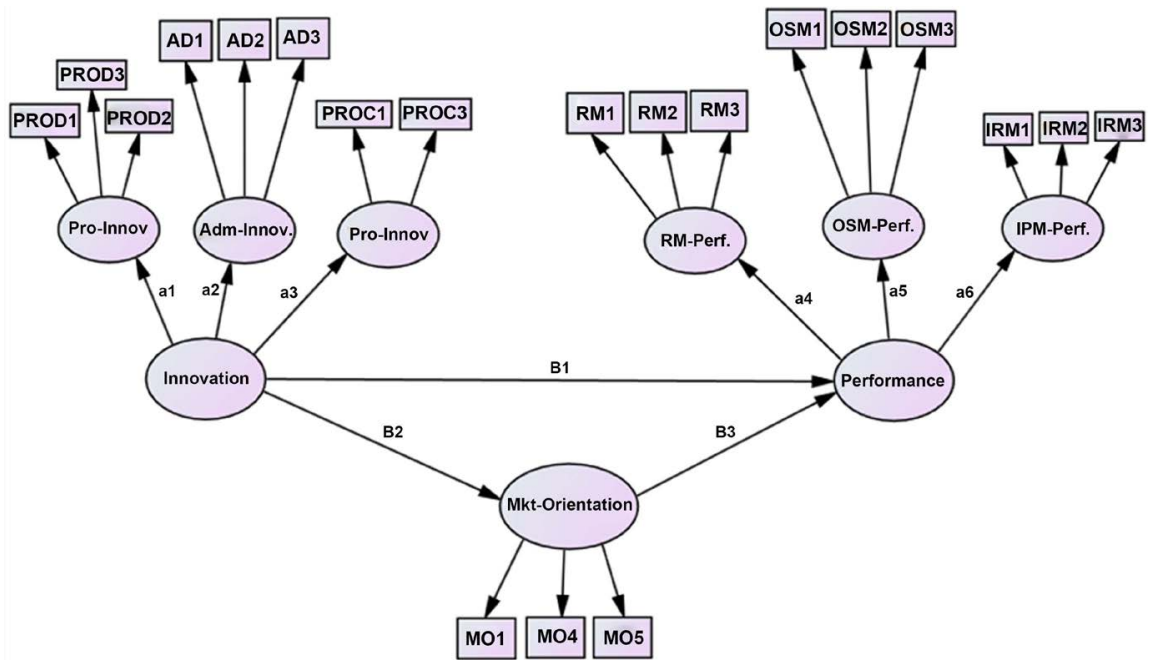

Figure 1. Structural model.

A confirmatory factor analysis was run to measure how well the variables represent the number of constructs. This helps to point potential weakness of specific weakness. The Confirmatory factor analysis results assert that some items need to be removed due to low standardized factor loading below is 0.30 . In the long run one item under process innovation (item 2) was deleted; two items under market orientation (item 2 and 3) were deleted and the whole items under the human relation model (item $1,2,3$ ) which was used to measure performance were deleted. This brought the final items to twenty.

The final fit of the model is satisfactory $\left(\chi^{2}=24.91, \mathrm{df}=12\right.$; GFI $=0.98$; RMSEA $=0.060$; CFI $=0.98$; TLI $=0.96$ ), suggesting that the nomological network of relationships fits the data. This is in relation to Hoyle and Panter (1995) recommendation for model of fit evaluation.

Descriptive statistics in this study employed the use of mean, standard deviation and correlation between constructs. Table 1, which determines the connection and direction of relationship for main variables and controls. The correlation matrix in Table 1 shows that there is a meaningful connection in direction to the hypothesized variables in this study. The outcomes suggested that there is a significant connection between RM (rational model), OSM (open-system model), IPM (internal process model), product innovation, process innovation, administrative innovation and market orientation.

In terms of the hypotheses, the first hypothesis H1: individual innovation types; process, product and administrative is positively linked to organizational performance seeks to analyze the direct relationship between innovation and performance. From Table 7 the findings for $\mathrm{H} 1$ (Innovation $\rightarrow$ performance; B1 $=0.96, p>0.000$ ) indicates that innovation has a positive and significant effect on performance. In other words when innovation increases performance also increases and vice versa. These results supports the general idea that innovation is a leads a company to the road of success. 
Table 7. Construct structural model.

\begin{tabular}{|c|c|c|c|c|c|}
\hline \multirow{2}{*}{ Linkage in Model } & \multicolumn{2}{|c|}{ Hypothesis } & \multicolumn{3}{|c|}{ Standardized Parameter Est. } \\
\hline & Number & Sign & Parameter & Estimate & T-value \\
\hline \multicolumn{6}{|l|}{ Hypothesis } \\
\hline Innovation $\rightarrow$ Performance & $\mathrm{H} 1$ & + & B1 & 0.96 & $6.34^{* * *}$ \\
\hline Market Orientation $\rightarrow$ Innovation & $\mathrm{HO}$ & + & B2 & 0.63 & $8.04^{* * *}$ \\
\hline Market Orientation $\rightarrow$ Performance & & - & B3 & 0.11 & -1.15 \\
\hline \multicolumn{6}{|l|}{ Second-Order Construct } \\
\hline Innovation $\rightarrow$ Production & & & al & 0.73 & a \\
\hline Innovation $\rightarrow$ Processing & & & a3 & 0.62 & $9.62^{* * *}$ \\
\hline Innovation $\rightarrow$ Administration & & & $\mathrm{a} 2$ & 0.55 & $8.05^{* * *}$ \\
\hline Performance $\rightarrow$ RM & & & $\mathrm{a} 4$ & 0.65 & a \\
\hline Performance $\rightarrow$ OSM & & & a5 & 0.63 & $8.66^{* * *}$ \\
\hline Performance $\rightarrow$ IPM & & & a6 & 0.74 & $9.56^{* * *}$ \\
\hline
\end{tabular}

Fit statistics for measurement model of 22 indicators for 9 constructs: $\chi^{2}(12)=24.91$; GFI $=0.976$; RMSEA $=0.060 ; \mathrm{CFI}=0.977 ;$ TLI $(\mathrm{NNFI})=0.959 . P$-Value $=0.015$. a: Fixed parameter.

The second hypothesis H2: Innovation has a mediating role between market orientation and performance was examined by modeling innovation as a mediating variable. The findings (Table 7) also provide support for (Market Orientation $\rightarrow$ Innovation $\rightarrow$ Performance-Innovation plays a mediating role between market orientation and performance-; $\mathrm{B} 2=0.63, p>0.000$ and $\mathrm{B} 3=-0.11, P>$ $-1.15)$. The estimate of the direct relationship between Market Orientation and Performance is negative and insignificant that is as market orientation increases performance decreases, as compared to the estimate B2 (the relationship between market orientation and innovation). The relationship between market orientation and innovation (B2) is positive and significant within the $95 \%$ confidence interval. The relationship suggests that when market orientation increases, innovation also increases. In this case the results clearly suggest that innovation acts as a mediator between market orientation and performance. A mediator is known to be an internal, inferring variable allowing a variable of criterion to be influenced by the antecedent. A mediation was necessary because it helped define the presence of a significant interference mechanism (innovation) between the antecedent variable (market orientation) and dependent variable (firm performance). Insightfully, for complete mediation, the presence of a mediating variable (innovation) is essential for the independent variable to affect the dependent variable. We can confidently conclude that, innovation only serves as a mediating factor between marketing orientation and performance.

\section{Discussion}

This paper examines the relation between innovation and performance. This study also analyzed the market orientation and performance link with innova- 
tion as a mediator. Although the literature indicates that innovation has a positive connection with results, further research needs to be done taking into consideration the various categories of innovation This prompted the researcher to conduct an empirical study to further examine the effect innovation has on a developing countries' output outcomes. The hypothesis was formed from related literatures and tested using data collected from telecommunications companies in Ghana's Accra region.

To previous literature, the out turn of this study gives supplementary evidence that creativity has a positive impact on success (Bierly \& Chakrabarti, 1996; Brown \& Eisenhard, 1995; Caves \& Ghemawat, 1992; Damanpour \& Evan, 1984; Damanpour et al., 1989; Hansen et al., 1999; Roberts, 1999; Schulz \& Jobe, 2001; Thornhill, 2006; Weerawardena et al., 2006; Wheelwright \& Clark, 1992). Such results correspond to other literatures (Baker \& Sinkula, 1999; Lewrick, 2009; Greenley, 1995; Zhou et al., 2005). However, the relationship between market orientation and performance was negative, meaning the performance is not influenced by market orientation. It can be inferred on the basis of these two results that innovation acts as a mediating position between business orientation and efficiency rather than a direct connection to success.

This study helps to bridge the innovation-performance inconsistency gap that is caused by differences in results. Also this study does not only use product innovation (Salavou \& Lioukas, 2003) as a measure for innovation but includes process and administrative. Most studies use organizational culture (Keskin, 2006; Lee \& Tsai, 2005) when analyzing the link between innovation and performance the link between organization and performance, my study differs by using market orientation. This finding contributes to studies conducted which demonstrate the mediating position of market of innovation on market orientation and performance (Agarwal et al., 2003; Sandvik \& Sandvik, 2003). This finding has both theoretical and practical implications.

From a theoretical perspective this study contributes to management theory by examining innovation as a mediating factor between business orientation and efficiency as well as efficiency-influencing innovation directly. This study also perfects existing literature by using telecommunications firms where creativity is vital to its survival. This research was also undertaken in an African country; this is significant because there were few studies at this location.

Our findings also confirm, in support of O'Cass and Ngo (2007), that creative culture is a significant precedent for $\mathrm{MO}$, and that it is a stronger success predictor than MO. Our study shows the need to efficiently deploy existing capital to promote MO implementation and thereby enhance firm performance. This research also examined process innovation, product innovation as well as administrative efficiency rather than overall innovation.

Based on our results, some significant organizational implications can be pointed out.

This research and prior studies on this subject have established the notion that 
creativity affects efficiency. The only thing left uncertain is the mechanism involved in this relationship (Han et al., 1998). This research discusses business orientation; a dimension that executives need to pay attention to. The relationship was positive as seen in this research when innovation was mediated between market orientation and results. Market orientation is a behavior or attitude which helps an organization's innovation improve.

A firm has been versatile and adapted to generate and incorporate new ideas about goods, processes, and techniques according to Kotter and Schlesinger (2008). In doing so, market awareness and creativity form a constructive partnership. A firm that pays attention to its customers increases its innovativeness as it will continue to produce new goods as well as processes to match its customers' ever-changing demands.

The following are a few suggestions that are consistent with the study findings; companies that rely on innovation need to set practical and acceptable targets while concentrating on their clients. Managers or company leaders must be diligent in forecasting and predicting future developments based on input from past experiences of consumers and existing goods and services.

Managers will work harder to develop their organizations' innovation dimension, since innovation is moving a company to the next level. However, managers should be cautious as creativity is a risk-taking and costly practice. Managers should be mindful of innovation related problems and adverse consequences, such as employee discontent and unwarranted changes (Simpson et al., 2006). Management should also function on the basis that creativity needs to interact together with other variables. A company should have a community promoting creativity. A company that encourages its workers to be innovative, participate in strategic innovation and take advantage of business opportunities is likely to thrive. Managers can create hard work, productive work, and an environment to promote organizational learning and dedication to priorities and objectives. Taking advantage of these factors improves the capacity of workers to produce new products or service ideas in an attempt to respond to consumer demands and improve the responsiveness of the company (Øgaard et al., 2005). Managers should be able to explore and play with the forms of innovation to reap the full benefits of innovation.

\section{Conclusion}

The objective of this study was to verify the connection between innovation and organizational success in Ghana's telecommunications sector. The study also sought to confirm the link with innovation as mediator between market orientation and results.

Relationship intensity was checked using a formal questionnaire and data obtained from telecommunications firms operating in Accra, Ghana. Structural Equation model was employed in this study.

With a satisfactory model fit, this study's overall findings verified the individ- 
ual relationship of the study's two hypotheses; individual forms of innovation are positively related to success; innovation has a mediating position between market orientation and efficiency. The study proved to be a significant positive relationship between competition, success and competition that acts as a mediating position between consumer orientation and efficiency. Hypothesis 1 and hypothesis 2 findings were consistent with other previous research.

\subsection{Limitations}

Every analysis has to include its limitations. The study based on telecoms companies especially the mobile network providers in Ghana's main region.

This analysis was limited to three constructs: innovation, market orientation and performance, future research may decide to explore with other internal variables.

The research also used simple, subjective performance measures. The use of subjective performance metrics has been accepted by previous studies. The measures in question are considered to correlate closely with objective measures.

Although this paper contributes to the existing literature on this subject, there is no doubt that further work is needed in this field. It is necessary to bear in mind that this paper is developed within a particular region and business sector. Study should also be cautious when generalizing these views and observations into various contexts.

\subsection{Future Research}

Prior to the limitations discussed in the above paragraph, this study has highlighted some necessary future research directions.

Future research may go beyond mobile network providers and also involve other companies in other sectors and extend its population to other Ghana cities. That will enhance the generalizability of the analysis. Future research may even decide to compare organizations from other sectors. This study may give different outcomes and different perspectives on innovation and performance

Future study may extend and include other internal variables of organization and an inclusive model.

With the concept as to why subjective measures are reliable, future researchers should combine both subjective and objective performance indicators to improve the strength of their findings.

\section{Conflicts of Interest}

The authors declare no conflicts of interest regarding the publication of this paper.

\section{References}

Agarwal, S., Krishna Erramilli, M., \& Dev, C. S. (2003). Market Orientation and Performance in Service Firms: Role of Innovation. Journal of Services Marketing, 17, 68-82. 
https://doi.org/10.1108/08876040310461282

Akande, O. O. (2011). Accounting Skill as a Performance Factor for Small Businesses in Nigeria. Journal of Emerging Trends in Economics and Management Sciences, 2, 372-378.

Amabile, T. M., Conti, R., Coon, H., Lazenby, J., \& Herron, M. (1996). Assessing the Work Environment for Creativity. Academy of Management Journal, 39, 1154-1184.

Anderson, J. C., \& Gerbing, D. W. (1988). Structural Equation Modelling in Practice: A Review and Recommended Two-Step Approach. Psychological Bulletin, 103, 411-423. https://doi.org/10.1037/0033-2909.103.3.411

Au, A. K., \& Tse, A. C. (1995). The Effect of Marketing Orientation on Company Performance in the Service Sector: A Comparative Study of the Hotel Industry in Hong Kong and New Zealand. Journal of International Consumer Marketing, 8, 77-87. https://doi.org/10.1300/J046v08n02 06

Augusto, M., \& Coelho, F. (2009). Market Orientation and New to the World Products: Exploring the Moderating Effects of Innovativeness, Competitive Strength, and Environmental Forces. Industrial Marketing Management, 38, 94-108.

https://doi.org/10.1016/j.indmarman.2007.09.007

Baer, M., \& Frese, M. (2003). Innovation Is Not Enough: Climates for Initiative and Psychological Safety, Process Innovations, and Firm Performance. Journal of Organizational Behavior, 24, 45-68. https://doi.org/10.1002/job.179

Bagheri, S. K., \& Di Minin, A. (2015). The Changing Competitive Landscape of the Global Upstream Petroleum Industry. Journal of World Energy Law and Business, 8, 1-19. https://doi.org/10.1093/jwelb/jwu036

Bagozzi, R. P., \& Yi, Y. (1998). On the Evaluation of Structural Equation Model. Journal of the Academy of Marketing Science, 16, 74-94. https://doi.org/10.1007/BF02723327

Baker, W. E., \& Sinkula, J. M. (1999). The Synergistic Effect of Market Orientation and Learning Orientation on Organizational Performance. Journal of the Academy of Marketing Science, 27, 411-427. https://doi.org/10.1177/0092070399274002

Balkin, D. B., Markaman, G. D., \& Gómez-Mejía, L. R. (2000). Is CEO Pay in High-Technology Firms Related to Innovation? Academy of Management Journal, 43, 1118-1129. https://doi.org/10.5465/1556340

Barney, J. B. (1991). Firm Resources and Sustained Competitive Advantage. Journal of Management, 17, 99-120. https://doi.org/10.1177/014920639101700108

Bierly, P., \& Chakrabarti, A. K. (1996). Generic Knowledge Strategies in the US Pharmaceutical Industry. Strategic Management Journal, 17, 123-135. https://doi.org/10.1002/smj.4250171111

Birley, S., \& Westhead, P. (1990). Growth and Performance Contrasts between "Types” of Small Firms. Strategic Management Journal, 11, 535-557. https://doi.org/10.1002/smj.4250110705

Breitschwerdt, D., Conet, A., Michor, L., Müller, N., \& Salmon, L. (2016). Performance and Disruption-A Perspective on the Automotive Supplier Landscape and Major Technology Trends. Hg. v. McKinsey \& Company, zuletzt gepru am.

Brennan, L., Ferdows, K., Godsell, J., Golini, R., Keegan, R., Kinkel, S. et al. (2015). Manufacturing in the World: Where Next? International Journal of Operations and Production Management, 35, 1253-1274. https://doi.org/10.1108/IJOPM-03-2015-0135

Brown, S. L., \& Eisenhard, K. M. (1995). Product Development: Past Research, Present Findings, and Future Directions. Academy of Management Review, 20, 343-378. https://doi.org/10.5465/amr.1995.9507312922 
Calantone, R. J., Cavusgil, S. T. T., \& Zhao, Y. (2002). Learning Orientation, Firm Innovation Capability, and Firm Performance. Industrial Marketing Management, 31, 515-524. https://doi.org/10.1016/S0019-8501(01)00203-6

Campo, S., Díaz, A. M., \& Yagüe, M. J. (2014). Market Orientation in Mid-Range Service, Urban Hotels: How to Apply the MKTOR Instrument. International Journal of Hospitality Management, 43, 76-86. https://doi.org/10.1016/j.ijhm.2014.08.006

Caves, R. E., \& Ghemawat, P. (1992). Identifying Mobility Barriers. Strategic Management Journal, 13, 1-12. https://doi.org/10.1002/smj.4250130102

Cefis, E., \& Ciccarelli, M. (2005). Profit Differentials and Innovation. Economics of Innovation and New Technology, 14, 43-61. https://doi.org/10.1080/1043859042000232160

Chang, H. H., Wong, K. H., \& Chiu, W. S. (2019). The Effects of Business Systems Leveraging on Supply Chain Performance: Process Innovation and Uncertainty as Moderators. Information \& Management, 56, Article ID: 103140. https://doi.org/10.1016/j.im.2019.01.002

Christensen, C. M., \& Bower, J. M. (1996). Customer Power, Strategic Investment and the failure of Leading Firms. Strategic Management Journal, 17, 197-218. https://doi.org/10.1002/(SICI)1097-0266(199603)17:3<197::AID-SMJ804>3.0.CO;2-U

Covin, J. G., Slevin, D. P., \& Heeley, M. B. (1999). Pioneers and Followers: Competitive Tactics, Environment and Firm Growth. Journal of Business Venturing, 15, 175-210. https://doi.org/10.1016/S0883-9026(98)00015-9

Cronin, J. J., \& Page, T. J. (1988). An Examination of the Relative Impact of Growth Strategies on Profit Performance. European Journal of Management, 22, 57-68. https://doi.org/10.1108/EUM0000000005268

Crossan, M. M., \& Apaydin, M. (2010). A Multi-Dimensional Framework of Organizational Innovation: A Systematic Review of the Literature. Journal of Management Studies, 47, 1154-1191. https://doi.org/10.1111/j.1467-6486.2009.00880.x

Cumby, J., \& Conrod, J. (2001). Non-Financial Performance Measures in the Canadian Biotechnology Industry. Journal of Intellectual Capital, 2, 261-272. https://doi.org/10.1108/14691930110400001

Damanpour, F. (1991). Organizational Innovation: A Meta-Analysis of Effects of Determinants and Moderators. Academy of Management Journal, 34, 550-590. https://doi.org/10.5465/256406

Damanpour, F., \& Evan, W. (1984). Organizational Innovation and Performance: The Problem of Organizational Lag. Administrative Science Quarterly, 29, 392-409. https://doi.org/10.2307/2393031

Damanpour, F., \& Evan, W. (1984). Organizational Innovation and Performance: The Problem of Organizational Lag. Administrative Science Quarterly, 29, 392-409. https://doi.org/10.2307/2393031

Damanpour, F., \& Gopalakrishnan, S. (1998). Theories of Organizational Structure and Innovation Adoption: The Role of Environmental Change. Journal of Engineering and Technology Management, 15, 1-24. https://doi.org/10.1016/S0923-4748(97)00029-5

Damanpour, F., \& Gopalakrishnan, S. (2001). The Dynamics of the Adoption of Products and Process Innovations in Organizations. Journal of Management Studies, 38, 45-65. https://doi.org/10.1111/1467-6486.00227

Damanpour, F., Szabat, K. A., \& Evan, W. M. (1989). The Relationship between Types of Innovation and Organizational Performance. Journal of Management Studies, 26, 
587-601. https://doi.org/10.1111/j.1467-6486.1989.tb00746.x

Damanpour, F., Walker, R. M., \& Avellaneda, C. N. (2009). Combinative Effects of Innovation Types and Organizational Performance: A Longitudinal Study of Service Organizations. Journal of Management Studies, 46, 650-675. https://doi.org/10.1111/j.1467-6486.2008.00814.x

Darroch, J., \& McNaugton, R. (2002). Examining the Link between Knowledge Management Practices and Types of Innovation. Journal of Intellectual Capital, 3, 210-222. https://doi.org/10.1108/14691930210435570

De Silva, M., Howells, J., \& Meyer, M. (2018). Innovation Intermediaries and Collaboration: Knowledge-Based Practices and Internal Value Creation. Research Policy, 47, 70-87. https://doi.org/10.1016/j.respol.2017.09.011

Deng, S., \& Dart, J. (1994). Measuring Market Orientation: A Multi-Factor, Multi-Item Approach. Journal of Marketing Management, 10, 725-742. https://doi.org/10.1080/0267257X.1994.9964318

Deshpandé, R., \& Farley, J. (2004). Organizational Culture, Market Orientation, Innovativeness, and Firm Performance: An International Research Odyssey. International Journal of Research in Marketing, 21, 3-22.

https://doi.org/10.1016/j.ijresmar.2003.04.002

Deshpandé, R., \& Farley, J. U. (1999). Executive Insights: Corporate Culture and Market Orientation: Comparing Indian and Japanese Firms. Journal of International Marketing, 7, 111e127. https://doi.org/10.1177/1069031X9900700407

Deshpandé, R., Farley, J. U., \& Webster Jr., F. E. (1993). Corporate Culture, Customer Orientation, and Innovativeness in Japanese Firms: A Quadrad Analysis. The Journal of Marketing, 57, 23-37. https://doi.org/10.1177/002224299305700102

Dewar, R. D., \& Dutton, J. E. (1986). The Adoption of Radical and Incremental Innovations: An Empirical Analysis. Management Science, 32, 1422-1433.

https://doi.org/10.1287/mnsc.32.11.1422

Dibrell, C., Craig, J. B., \& Hansen, E. N. (2011). How Managerial Attitudes toward the Natural Environment Affect Market Orientation and Innovation. Journal of Business Research, 64, 401-407. https://doi.org/10.1016/j.jbusres.2010.09.013

Drucker, P. (1985). Innovation and Entrepreneurship. New York: Harper \& Row.

Evan, W. (1966) The Organization Set: Towards a Theory of Interorganizational Relations. In J. Thompson (Ed.), Approaches in Organization Design (pp. 173-191). Pittsburg, PA: Pittsburg University Press.

Fornell, C., \& Larcker, D. F. (1981). Evaluating Structural Equation Models with Unobservable Variables and Measurement Error. Journal of Marketing Research, 18, 39-50. https://doi.org/10.1177/002224378101800104

García-Morales, V. J., Jiménez-Barrionuevo, M. M. and Gutiérrez-Gutiérrez, L. (2011). Transformational Leadership Influence on Organizational Performance through Organizational Learning and Innovation. Journal of Business Research, 65, 1040-1050. https://doi.org/10.1016/j.jbusres.2011.03.005

Gómez, J., Salazar, I., \& Vargas, P. (2017). Does Information Technology Improve Open Innovation Performance? An Examination of Manufacturers in Spain. Information Systems Research, 28, 661-675. https://doi.org/10.1287/isre.2017.0705

Gotteland, D., \& Boule, J. M. (2006). The Market Orientation-New Product Performance Relationship: Redefining the Moderating Role of Environmental Conditions. International Journal of Research in Marketing, 23, 171-185. 
https://doi.org/10.1016/j.ijresmar.2005.08.001

Greenley, G. E. (1995). Market Orientation and Company Performance: Empirical Evidence from UK Companies. British Journal of Management, 6, 1-13. https://doi.org/10.1111/j.1467-8551.1995.tb00082.x

Guan, J., \& Ma, N. (2003). Innovative Capability and Export Performance of Chinese Firms. Technovation, 23, 737-747. https://doi.org/10.1016/S0166-4972(02)00013-5

Gunday, G., Ulusoy, G., Kilic, K., \& Alpkan, L. (2011). Effects of Innovation on Firm Performance. International Journal of Production Economics, 133, 662-676. https://doi.org/10.1016/j.ijpe.2011.05.014

Guo, C. (2002). Market Orientation and Business Performance: A Framework for Service Organizations. European Journal of Marketing, 36, 1154-1163. https://doi.org/10.1108/03090560210437389

Guo, R. J., Baruch, L., \& Zhou, N. (2005). The Valuation of Biotech IPOs. Journal of Accounting, Auditing \& Finance, 20, 423-459. https://doi.org/10.1177/0148558X0502000407

Hage, J. (1980). Theories of Organizations. New York: Wiley.

Hair, J. F., Anderson, R. E., Tatham, R. L., Black, W. C., Babin, B. J., \& Anderson, R. E. (2010). Multivariate Data Analysis (7th ed.). Upper Saddle River, NJ: Pearson Prentice Hall.

Haleem, A., Kumar, S., \& Luthra, S. (2018). Flexible System Approach for Understanding Requisites of Product Innovation Management. Global Journal of Flexible Systems Management, 19, 9-37. https://doi.org/10.1007/s40171-017-0171-7

Hamon, T. T. (2003). Organizational Effectiveness as Explained by Social Structure in a Faith-Based Business Network Organization. Unpublished Doctoral Dissertation, Virginia Beach, VA: Regent University.

Han, J. K., Kim, N., \& Shrivastava, R. (1998). Market Orientation and Organizational Performance: Is Innovation a Missing Link? Journal of Marketing, 62, 30-45. https://doi.org/10.1177/002224299806200403

Hansen, M., Nohria, T., \& Tierney, T. (1999). What's Your Strategy for Managing Knowledge? Harvard Business Review, 77, 106-116.

Haring, J. (2002). Telecommunications. The Concise Encyclopedia of Economics. Library of Economics and Liberty.

https://www.econlib.org/library/Enc1/Telecommunications.html

Hashi, I., \& Stojčić, N. (2013). The Impact of Innovation Activities on Firm Performance Using a Multi-Stage Model: Evidence from the Community Innovation Survey 4. Research Policy, 42, 353-366. https://doi.org/10.1016/j.respol.2012.09.011

Hatzikian, Y. (2013). Exploring the Link between Innovation and Firm Performance. Journal of the Knowledge Economy, 6, 749-768. https://doi.org/10.1007/s13132-012-0143-2

Heskett, J. L., \& Schlesinger, L. (1994). Putting the Service-Profit Chain to Work. Harvard Business Review, 72, 164-174.

Heunks, F. J. (1998). Innovation, Creativity and Success. Small Business Economics, 10, 263-272. https://doi.org/10.1023/A:1007968217565

Hoyle, R. H., \& Panter, A. T. (1995). Writing about Structural Equation Modeling. In R. H. Hoyle (Ed.), Structural Equation Modelling (pp. 158-176). Thousand Oaks, CA: Sage.

Hult, G. T. M., \& Ketchen, D. J. (2001). Does Market Orientation Matter? A Test of the 
Relationship between Positional Advantage and Performance. Strategic Management Journal, 22, 899-906. https://doi.org/10.1002/smj.197

Hult, G. T., Ketchen, D. J., \& Slater, S. F. (2005). Market Orientation and Performance: An Integration of Disparate Approaches. Strategic Management Journal, 26, 1173-1181. https://doi.org/10.1002/smj.494

Hurley, R., \& Hult, G. (1998). Innovation, Market Orientation, and Organizational Learning: An Integration and Empirical Examination. Journal of Marketing, 62, 42-54. https://doi.org/10.1177/002224299806200303

Jajja, M. S. S., Kannan, V. R., Brah, S. A., \& Hassan, S. Z. (2017). Linkages between Firm Innovation Strategy, Suppliers, Product Innovation, and Business Performance: Insights from Resource Dependence Theory. International Journal of Operations and Production Management, 37, 1054-1075. https://doi.org/10.1108/IJOPM-09-2014-0424

Jiménez-Jiménez, D., \& Sanz-Valle, R. (2011). Innovation, Organizational Learning, and Performance. Journal of Business Research, 64, 408-417.

https://doi.org/10.1016/j.jbusres.2010.09.010

Jiménez-Jiménez, D., Sanz-Valle, R., \& Rodriguez-Espallardo, M. (2008). Fostering Innovation: The Role of Market Orientation and Organizational Learning. European Journal of Innovation Management, 11, 389-412.

https://doi.org/10.1108/14601060810889026

Johne, A., \& Davies, R. (2000). Innovation in Medium-Sized Insurance Firms: How Marketing Adds Value. International Journal of Bank Marketing, 18, 6-14. https://doi.org/10.1108/02652320010315316

Keskin, H. (2006). Market Orientation, Learning Orientation, and Innovation Capabilities in SMEs. European Journal of Innovation Management, 9, 396-417. https://doi.org/10.1108/14601060610707849

Kirca, A. H., Jayachandran, S., \& Bearden, W. O. (2005). Market Orientation: A Meta-AnalyticReview and Assessment of Its Antecedents and Impact on Performance. Journal of Marketing, 69, 24-41. https://doi.org/10.1509/jmkg.69.2.24.60761

Knight, K. (1967). A Descriptive Model of the Intra-Firm Innovation Process. The Journal of Business, 40, 478-496. https://doi.org/10.1086/295013

Koc, T., \& Ceylan, C. (2007). Factors Impacting the Innovative Capacity in Large-Scale Companies. Technovation, 27, 105-114.

https://doi.org/10.1016/j.technovation.2005.10.002

Koellinger, P. (2008). The Relationship between Technology, Innovation, and Firm Performance-Empirical Evidence from e-Business in Europe. Research Policy, 37, 1317-1328. https://doi.org/10.1016/j.respol.2008.04.024

Kohli, A. K., \& Jaworski, B. J. (1990). Market Orientation: The Construct, Research Propositions, and Managerial Implications. Journal of Marketing, 54, 1-18. https://doi.org/10.1177/002224299005400201

Kohli, A. K., Jaworski, B. J., \& Kumar, A. (1993). Markor: A Measure of Market Orientation. Journal of Marketing Research, 30, 467-477. https://doi.org/10.1177/002224379303000406

Kotter, J. P., \& Schlesinger, L. A. (2008). Choosing Strategies for Change. Harvard Business Review, 86, 130-139.

Kumar, V., Jones, E., Venkatesan, R., \& Leone, R. P. (2011). Is Market Orientation a Source of Sustainable Competitive Advantage or Simply the Cost of Competing? Journal of Marketing, 75, 16-30. https://doi.org/10.1509/jmkg.75.1.16

Lado, N., \& Maydeu-Olivares, A. (2001). Exploring the Link between Market Orientation 
and Innovation in the European and US Insurance Markets. International Marketing Review, 18, 130-144. https://doi.org/10.1108/02651330110389972

Lam, A. (2004). Organizational Innovation. Brunel Research in Enterprise, Innovation, Sustainability \& Ethics, Working Papers No. 1.

Lambin, J. J. (1996). The Misunderstanding about Marketing. CEMS Business Review, 1, 37-56.

Leal-Rodríguez, A. L., Eldridge, S., Roldán, J. L., Leal-Millán, A. G., \& Ortega-Gutiérrez, J. (2015). Organizational Unlearning, Innovation Outcomes, and Performance: The Moderating Effect of Firm Size. Journal of Business Research, 68, 803-809.

https://doi.org/10.1016/j.jbusres.2014.11.032

Lee, K. S., \& Ng, I. C. L. (2001). Advanced Sale of Service Capacities: A Theoretical Analysis of the Impact of Price Sensitivity on Pricing and Capacity Allocations. Journal of Business Research, 54, 219-225. https://doi.org/10.1016/S0148-2963(00)00119-3

Lee, T.-S., \& Tsai, H.-J. (2005). The Effects of Business Operation Mode on Market Orientation, Learning Orientation and Innovativeness. Industrial Management \& Data Systems, 105, 325-348. https://doi.org/10.1108/02635570510590147

Lee, Y. K., Kim, S. H., Seo, M. K., \& Hight, K. S. (2015). Market Orientation and Business Performance: Evidence from Franchising Industry. International Journal of Hospitality Management, 44, 28-37. https://doi.org/10.1016/j.ijhm.2014.09.008

Lenssen, G., Tyson, S., Pickard, S., Bevan, D., \& Bartlett, D. (2009). Embedding Corporate Responsibility: The Development of a Transformational Model of Organizational Innovation. Corporate Governance, 9, 409-420.

https://doi.org/10.1108/14720700910984963

Lewrick, M. (2009). Introduction of an Evaluation Tool to Predict the Probability of Success of Companies: The Innovativeness, Capabilities and Potential Model (ICP). Journal of Technology Management and Innovation, 4, 33-47. https://doi.org/10.4067/S0718-27242009000100004

Li, H., \& Atuahene-Gima, K. (2001). Product Innovation Strategy and the Performance of New Technology Ventures in China. Academy of Management Journal, 44, 1123-1134.

Liu, S. (2009). Organizational Culture and New Service Development Performance: Insights from Knowledge Intensive Business Service. International Journal of Innovation Management, 13, 371-392. https://doi.org/10.1142/S1363919609002340

Lyon, D., \& Ferrier, W. (2002). Enhancing Performance with Product-Market Innovation: The Influence of the Top Management Team. Journal of Management, 14, 452-469.

Mansury, M. A., \& Love, J. H. (2008). Innovation, Productivity and Growth in US Business Services: A Firm-Level Analysis. Technovation, 28, 52-62.

https://doi.org/10.1016/j.technovation.2007.06.002

Marques, S. C., Gerry, C., Covelo, S., Braga, V., \& Braga, A. (2011). Innovation and the Performance of Portuguese Businesses: A “SURE” Approach. International Journal of Management and Enterprise Development, 10, 114-128.

https://doi.org/10.1504/IJMED.2011.041545

Moullin, M. (2003). Defining Performance Measurement. Perspectives on Performance, $2,3$.

Najafi-Tavani, S., Najafi-Tavani, Z., Naudé, P., Oghazi, P., \& Zeynaloo, E. (2018). How Collaborative Innovation Networks Affect New Product Performance: Product Innovation Capability, Process Innovation Capability, and Absorptive Capacity. Industrial Marketing Management, 73, 193-205. https://doi.org/10.1016/j.indmarman.2018.02.009 
Narver, J. C., \& Slater, S. F. (1990). The Effect of a Market Orientation on Business Profitability. Journal of Marketing, 54, 20-35. https://doi.org/10.1177/002224299005400403

Narver, J. C., Slater, S. F., \& MacLachlan, D. L. (2004). Responsive and Proactive Market Orientation and New-Product Success. Journal of Product Innovation Management, 21, 334-347. https://doi.org/10.1111/j.0737-6782.2004.00086.x

Nord, W., \& Tucker, S. (2001). Implementing Routine and Radical Innovations. Lexington, MA: Lexington Books.

Normann, R. (1971). Organizational Innovativeness: Product Variation and Reorientation. Administrative Science Quarterly, 16, 203-215. https://doi.org/10.2307/2391830

O’Cass, A., \& Ngo, L. (2007). Market Orientation versus Innovative Culture: Two Routes to Superior Brand Performance. European Journal of Marketing, 41, 868-887. https://doi.org/10.1108/03090560710752438

OECD (2010). Launch of the OECD's Innovation Strategy. http://www.oecd.org/document/12/0,3343,en $2469 \quad 34273 \quad 45330700 \quad 1 \quad 1 \quad 1 \quad 1$, 00. html

Øgaard, T., Larsen, S., \& Marnburg, E. (2005). Organizational Culture and Performance Evidence from the Fast Food Restaurant Industry. Food Service Technology, 5, 23-34. https://doi.org/10.1111/j.1471-5740.2005.00109.x

Olavarrieta, S., \& Friedmann, R. (2008). Market Orientation, Knowledge Related Resources and Firm Performance. Journal of Business Research, 61, 623-630.

https://doi.org/10.1016/j.jbusres.2007.06.037

Omri, W. (2015). Innovative Behavior and Venture Performance of SMEs: The Moderating Effect of Environmental Dynamism. European Journal of Innovation Management, 18, 195-217. https://doi.org/10.1108/EJIM-02-2013-0015

Peña, A. I. P., Jamilena, D. M. F., \& Molina, M. A. R. (2012). Market Orientation as a Strategy for the Rural Tourism Sector: Its Effect on Tourist Behavior and the Performance of Enterprises. Journal of Travel Research, 52, 225-239.

https://doi.org/10.1177/0047287512459108

Piening, E. P., \& Salge, T. O. (2015). Understanding the Antecedents, Contingencies, and Performance Implications of Process Innovation: A Dynamic Capabilities Perspective. Journal of Product Innovation Management, 32, 80-97. https://doi.org/10.1111/jpim.12225

Quinn, R. E., \& Rohrbaugh, J. (1983). A Spatial Model of Effectiveness Criteria: Towards a Competing Values Approach to Organizational Analysis. Management Science, 29, 363-377. https://doi.org/10.1287/mnsc.29.3.363

Robbins, S. P., \& Coulter, M. (2002). Management. Upper Saddle River, NJ: Prentice Hall.

Roberts, P. W. (1999). Product Innovation, Product-Market Competition and Persistent Profitability in the U.S. Pharmaceutical Industry. Strategic Management Journal, 20, 655-670.

https://doi.org/10.1002/(SICI)1097-0266(199907)20:7<655::AID-SMJ44>3.0.CO;2-P

Rogers, E. M. (1995). Diffusion of Innovations. New York: The Free Press.

Rosenbusch, N., Brinckmann, J., \& Bausch, A. (2011). Is Innovation Always Beneficial? A Meta-Analysis of the Relationship between Innovation and Performance in SMEs. Journal of Business Venturing, 26, 441-457.

https://doi.org/10.1016/j.jbusvent.2009.12.002

Ruekert, R. W. (1992). Developing a Market Orientation: An Organizational Strategy Perspective. International Journal of Research in Marketing, 9, 225-245. https://doi.org/10.1016/0167-8116(92)90019-H 
Salavou, H., \& Lioukas, S. (2003). Radical Product Innovations in SMEs: The Dominance of Entrepreneurial Orientation. Creativity and Innovation Management, 12, 94-108. https://doi.org/10.1111/1467-8691.00272

Sandvik, I. L., \& Sandvik, K. (2003). The Impact of Market Orientation on Product Innovativeness and Business Performance. International Journal of Research in Marketing, 20, 355-376. https://doi.org/10.1016/j.ijresmar.2003.02.002

Santos, D. F. L., Basso, L. F. C., Kimura, H., \& Kayo, E. K. (2014). Innovation Efforts and Performances of Brazilian Firms. Journal of Business Research, 67, 527-535. https://doi.org/10.1016/j.jbusres.2013.11.009

Sargeant, A., \& Mohamad, M. (1999). Business Performance in the UK Hotel Sector Does It Pay to Be Market Oriented? Service Industries Journal, 19, 42-59. https://doi.org/10.1080/02642069900000029

Schulz, M., \& Jobe, L. A. (2001). Codification and Tacitness as Knowledge Management Strategies: An Empirical Exploration. Journal of High Technology Management Research, 12, 139-165. https://doi.org/10.1016/S1047-8310(00)00043-2

Shariff, M. N. M., Peou, C., \& Ali, J. (2010). Moderating Effect of Government Policy on Entrepreneurship and Growth Performance of Small-Medium Enterprises in Cambodia. International Journal of Business and Management Science, 3, 57-72.

Simpson, P. M, Siguaw, J. A., \& Enz, C. A. (2006). Innovation Orientation Outcomes: The Good and the Bad. Journal of Business Research, 59, 1133-1141. https://doi.org/10.1016/j.jbusres.2006.08.001

Slater, S. F., \& Narver, J. C. (1998). Market Orientation Is More than Being Customer Led: And Customer Led: Let's Not Confuse the Two. Strategic Management Journal, 19, 1001-1006.

https://doi.org/10.1002/(SICI)1097-0266(199810)19:10<1001::AID-SMJ996>3.0.CO;2-4

Srivastava, R. K., Fahey, L., \& Christensen, H. K. (2001). The Resource Based View and Marketing: The Role of Market Based Assets in Gaining Competitive Advantage. Journal of Management, 27, 777-802. https://doi.org/10.1177/014920630102700610

Subramaniam, M., \& Youndt, M. A. (2005). The Influence of Intellectual Capital on the Types of Innovative Capabilities. Academy of Management Journal, 48, 450-463. https://doi.org/10.5465/amj.2005.17407911

Tellis, G. J., Prabhu, J. C., \& Chandy, R. K. (2009). Radical Innovation across Nations: The Preeminence of Corporate Culture. Journal of Marketing, 73, 3-23. https://doi.org/10.1509/jmkg.73.1.003

Thompson, V. A. (1965). Bureaucracy and Innovation. Administrative Science Quarterly, 10, 1-20. https://doi.org/10.2307/2391646

Thornhill, S. (2006). Knowledge, Innovation and Firm Performance in High- and Low-Technology Regimes. Journal of Business Venturing, 21, 687-703. https://doi.org/10.1016/j.jbusvent.2005.06.001

Tidd, J., Bessant, J., \& Pavitt, K. (2001). Managing Innovation. Chichester: Wiley.

Tirupati, D. (2008). Role of Technological Innovations for Competitiveness and Entrepreneurship. The Journal of Entrepreneurship, 17, 103-115. https://doi.org/10.1177/097135570801700201

Tuan, N., Nhan, N., Giang, P., \& Ngoc, N. (2016). The Effects of Innovation on Firm Performance of Supporting Industries in Hanoi, Vietnam. Journal of Industrial Engineering and Management, 9, 413-431. https://doi.org/10.3926/jiem.1564

Tushman, M. L., \& Nadler, D. A. (1986). Organizing for Innovation. California Manage- 
ment Review, 28, 74-92. https://doi.org/10.2307/41165203

Tyler, B. B. (2001). The Complementarity of Cooperative and Technological Competencies: A Resource-Based Perspective. Journal of Engineering and Technology Management, 18, 1-27. https://doi.org/10.1016/S0923-4748(00)00031-X

Utterback, J. M. (1994). Mastering the Dynamics of Innovation: How Companies Can Seize Opportunities in the Face of Technological Change. Boston, MA: Harvard Business School Press.

Utterback, J. M., \& Abernathy, W. (1975). A Dynamic Model of Product and Process Innovation. Omega, 3, 639-656. https://doi.org/10.1016/0305-0483(75)90068-7

Venkatraman, N., \& Ramanujam, V. (1986). Measurement of Business Performance in Strategy Research: A Comparison of Approaches. Academy of Management Review, 11, 801-814. https://doi.org/10.5465/amr.1986.4283976

Vincent, L. H., Bharadwaj, S. G., \& Challagalla, G. N. (2004). Does Innovation Mediate Firm Performance?: A Meta-Analysis of Determinants and Consequences of Organizational Innovation. Atlanta, GA: Georgia Institute of Technology.

Vrakking, W. J. (1990). The Innovative Organization. Long Range Planning, 23, 94-102. https://doi.org/10.1016/0024-6301(90)90204-H

Walker, G. (2009). Modern Competitive Strategy (3rd ed.). Singapore: The McGraw-Hill.

Wang, C. H., Chen, K. Y., \& Chen, S. C. (2012). Total Quality Management, Market Orientation and Hotel Performance: The Moderating Effects of External Environmental Factors. International Journal of Hospitality Management, 31, 119-129.

https://doi.org/10.1016/j.ijhm.2011.03.013

Wang, C. L., \& Ahmed, P. K. (2004). The Development and Validation of the Organizational Innovativeness Construct Using Confirmatory Factor Analysis. European Journal of Innovation Management, 7, 303-313.

https://doi.org/10.1108/14601060410565056

Weerawardena J., O'Cass A., \& Julian, C. (2006). Does Industry Matter? Examining the Role of Industry Structure and Organizational Learning in Innovation and Brand Performance. Journal of Business Research, 59, 37-45.

https://doi.org/10.1016/j.jbusres.2005.02.004

Wheelwright, S. C., \& Clark, K. B. (1992). Revolutionizing Product Development: Quantum Leaps in Speed, Efficiency and Quality. New York: The Free Press.

Wolfe, R. A. (1994). Organizational Innovation: Review, Critique and Suggested Research Directions. Journal of Management Studies, 31, 405-431. https://doi.org/10.1111/j.1467-6486.1994.tb00624.x

Wright, R. E., Palmer, J. C., \& Perkings, D. (2005). Types of Product Innovations an Small Business Performance in Hostile and Benign Environments. Journal of Small Business Strategy, 15, 33-44.

Xue, Y., Liang, H., \& Boulton, W. R. (2008). Information Technology Governance in Information Technology Investment Decision Processes: The Impact of Investment Characteristics, External Environment, and Internal Context. MIS Quarterly: Management Information Systems, 32, 67-96. https://doi.org/10.2307/25148829

Yaseen, S. G., Dajani, D., \& Hasan, Y. (2016). The Impact of Intellectual Capital on the Competitive Advantage: Applied Study in Jordanian Telecommunication Companies. Computers in Human Behavior, 62, 168-175. https://doi.org/10.1016/j.chb.2016.03.075

Zaefarian, G., Forkmann, S., Mitrega, M., \& Henneberg, S. C. (2017). A Capability Perspective on Relationship Ending and Its Impact on Product Innovation Success and 
Firm Performance. Long Range Planning, 50, 184-199.

https://doi.org/10.1016/j.lrp.2015.12.023

Zhou, K., Yim, C., \& Tse, D. (2005). The Effects of Strategic Orientations on Technologyand Market-Based Breakthrough Innovations. Journal of Marketing, 69, 42-60. https://doi.org/10.1509/jmkg.69.2.42.60756 